\title{
Habitat features and zooplankton community structure of oxbows in the limnophase: reference to transitional phase between flooding and stabilization
}

\author{
Tomasz Joniak* and Natalia Kuczyńska-Kippen
}

Adam Mickiewicz University in Poznań, Faculty of Biology, Department of Water Protection, Umultowska str. 89, 61-614 Poznań, Poland.

*Corresponding author: tjoniak@amu.edu.pl

Received: 12/12/2014

Accepted: 21/07/2015

\begin{abstract}
Habitat features and zooplankton community structure of oxbows in the limnophase: reference to transitional phase between flooding and stabilization

Due to their origin and their morphometric and hydrodynamic parameters, oxbow lakes represent a distinct type of aquatic ecosystem, especially compared with post-glacial lakes. The functioning of oxbows is directly and indirectly connected with temporal fluctuations of the water level in rivers. Periodic inundation of floodplain habitats provides primary producers with access to mineral and organic compounds, creates refuge conditions for aquatic organisms against disturbances in the river channel, and contributes to the increase of biodiversity in the whole river system. To determine the best predictors of zooplankton community indices, as well as those of rotifer and crustacean species, we examined them with respect to the following environmental parameters: the type of habitat, the type of land uses, the shading of the lake's surface and the presence of fish. The study was performed on oxbows during limnophase. Despite the fact that the biotic structure in oxbows may be simplified, it was found that a high level of habitat complexity positively influences zooplankton species richness and the Shannon-Weaver index of diversity. This would support the fact that during limnophase, oxbows are in an ecotonal phase - between the flooding and the stabilization period. In contrast to other types of small water bodies, the type of land uses (forest vs. field) that affected the quality of the supplies of organic and mineral compounds, along with the presence of fish, did not have a pronounced effect on either zooplankton diversity or their community abundance. Particular zooplankton species also exhibited habitat segregation in accordance with their ecological group (pelagic vs. littoral species) or taxonomic affiliation (rotifers vs. crustaceans). Littoral species, attributed to elodeids, preferred oxbows with a high degree of overshading. Among the pelagic zooplankton, which preferred to remain in the open water zone, a large representation of eutrophic species was recorded due to the overload of the water by mineral nutrients and organic matter. The high zooplankton diversity of the studied aquatic ecosystems and the abiotic features, which revealed an unstable and disturbed status, confirmed the fact that oxbows during the limnophase reflect an ecotonal phase. This may be a complementation to the river flood pulse concept.
\end{abstract}

Key words: oxbow lakes, land use, hydrochemistry, zooplankton, river floods, natural disturbances.

\section{RESUMEN}

Características del hábitat y de la estructura de la comunidad de zooplancton en un meandro abandonado durante la limnofase: con referencia al periodo de transición entre la inundación y estabilización

Debido a su origen, morfometría e hidrodinamismo, los meandros abandonados representan un tipo de ecosistema lacustre particular, especialmente si se comparan con lagos de origen glaciar. El funcionamiento de los meandros abandonados, está directa o indirectamente relacionado con las fluctuaciones temporales del nivel del agua del río. Las inundaciones periódicas de los hábitats de la llanura fuvial aportan minerales y compuestos orgánicos a los productores primarios, crean refugio a los organismos acuáticos frente a perturbaciones en el canal del río y contribuyen al incremento de la biodiversidad en todo el sistema fluvial. Con el objetivo de conocer los predictores de la comunidad de zooplancton, así como de las especies de rotíferos y crustáceos, comparamos la composición taxonómica con algunos parámetros ambientales: tipo de hábitat, usos del suelo, sombra en la superficie del lago y presencia de peces. El estudio se realizó en meandros abandonados durante la limnofase. A pesar de que la estructura de la comunidad en estos sistemas pudiera ser sencilla, se encontró que la complejidad 
del hábitat favorecía la riqueza de especies y la diversidad de Shannon-Weaver del zooplankton. Esto confirma el hecho de que durante la limnofase, estos hábitats son ecotonos entre el periodo de inundación y el de estabilización. A diferencia de lo que ocurre en otros tipos de cuerpos de agua de menor tamaño, el uso del suelo (bosque vs campo), que determina la calidad de los compuestos orgánicos y minerales aportados, junto con la presencia de peces, no afectaron notablemente ni la diversidad ni la abundancia de la comunidad de zooplancton en los sistemas estudiados. Algunas especies de zooplancton mostraron una segregación de hábitat de acuerdo a su grupo ecológico (especies pelágicas vs especies litorales) o a su afiliación taxonómica (rotíferos vs crustáceos). Las especies litorales, relacionadas con la presencia de macrófitos, prefieren lagunas con un alto grado de sombra. Dentro de las especies pelágicas de zooplancton, que prefieren permanecer en la zona de aguas abiertas, se registraron una gran cantidad de especies eutróficas, debido a la alta carga de nutrientes y materia orgánica. La gran diversidad de zooplancton de los ecosistemas estudiados y las características abióticas revelan el estado de inestabilidad y perturbación de estos sistemas y su papel como zona de transición. Estos resultados pueden complementar el conocido Flood Pulse Concept.

Palabras clave: meandros abandonados, usos del suelo, hidroquímica, zooplancton, inundaciones, perturbaciones naturales.

\section{INTRODUCTION}

As small-sized systems, small water bodies have a significant influence on maintaining the biological diversity and the networks of ecological associations within a landscape (Symonides, 2010). The natural value of these environmental islands and their impact on the functioning of ecological linkages in the landscape depends on their spatial structure and morphometric parameters, as well as on their degree of isolation. In the case of oxbows, a river plays the role of a natural link between similar areas within the landscape.

Water habitats in river valleys are formed by interactions among hydrological and geomorphological elements. The dynamic nature of these habitats is driven primarily by characteristics of the flow regime, which is most obvious during flooding when ephemeral habitats such as oxbows and other floodplains can be inundated (Humphries et al., 2006). Meandering rivers are responsible for forming oxbow lakes. The oscillations that occur in the river level have a powerful impact on the connection between the river and the oxbows. Such a connection depends on different factors, e.g., morphometric features, position and also the area of the body of water (Güntzel et al., 2010). Such phenomena will in turn have a pronounced effect on the physical-chemical parameters of the water ( $\mathrm{Ga}$ llardo et al., 2012) and thus on the qualitative and quantitative structure of the inhabiting plankton habitats (Wilk-Woźniak et al., 2013).

Oxbows create a multiplicity of habitats and feeding grounds for various organisms e.g., birds, fish, amphibians, macroinvertebrates and phytoplankton (Jurkiewicz-Karnkowska, 2006; Obolewski et al., 2009; Obolewski, 2011; Grabowska et al., 2014). The zooplankton inhabiting oxbow water bodies are usually much more complex taxonomically, as well as more abundant than potamoplankton, which results from the more stable environmental conditions prevailing in oxbows compared with the neighbouring river (Napiórkowski, 2012). Although some studies on this type of aquatic ecosystem have already been undertaken (Pasztaleniec et al., 2013), the recognition of zooplankton assemblages, as well as the understanding of trophic relationships in oxbow reservoirs, is still limited. The specific aims of the present work included an analysis of the species composition, zooplankton community abundance and Shannon-Weaver index of diversity in relation to both the abiotic and biotic parameters of the oxbow environment. Moreover, the distribution of particular zooplankton indices, as well as environmental factors, was also analysed to determine the best predictors of rotifer and crustacean species occurrence from among (1) the type of examined habitat, (2) the type of land use, (3) the presence of fish in a pond, (4) the coverage of pleustophytes on the 
pond's surface and (5) the physical-chemical features of the water.

The study was also carried out to find out whether the structure of the zooplankton communities inhabiting the oxbows of the examined glacial valley of the River Warta would be uniform and simplified compared with that of typical post-glacial ponds, which predominate in Poland as oxbows undergo frequent flooding. This may lead to the elimination of planktonic organisms and aquatic vegetation (Cronk \& Fennessy, 2001; Gallardo et al., 2012). However, we hypothesized that during limnophase, oxbows such as those examined in our study are in an ecotonal phase $-\mathrm{a}$ transition between the flooding and the stabilization period. Therefore, we expected that zooplankton diversity would be very high. According to the definition of ecotons, species diversity can be high (Lachavanne \& Raphä̈lle, 1997). This definition can also refer to wetland ecotones, which may support relatively high biological diversity. As oxbows belong to lotic systems, periodic disturbances may be more important than limiting factors in creating and maintaining the entire system (Naiman \& Décamps, 1990).

\section{STUDY AREA}

The oxbows were located within the middle section of the River Warta Valley, which is one of the most valuable regions of the Wielkopolska region (central-western Poland) (Fig. 1). The Warta is a large-size river, the major right tributary of the River Odra, and the third largest river in Poland. It is $808 \mathrm{~km}$ long, and its catchment area accounts for approximately $1 / 6$ of the area of Poland (Szelag-Wasielewska et al., 2009). The annual average discharge of the river is $111 \mathrm{~m}^{3} / \mathrm{s}$. Floods occur irregularly; however, in the years

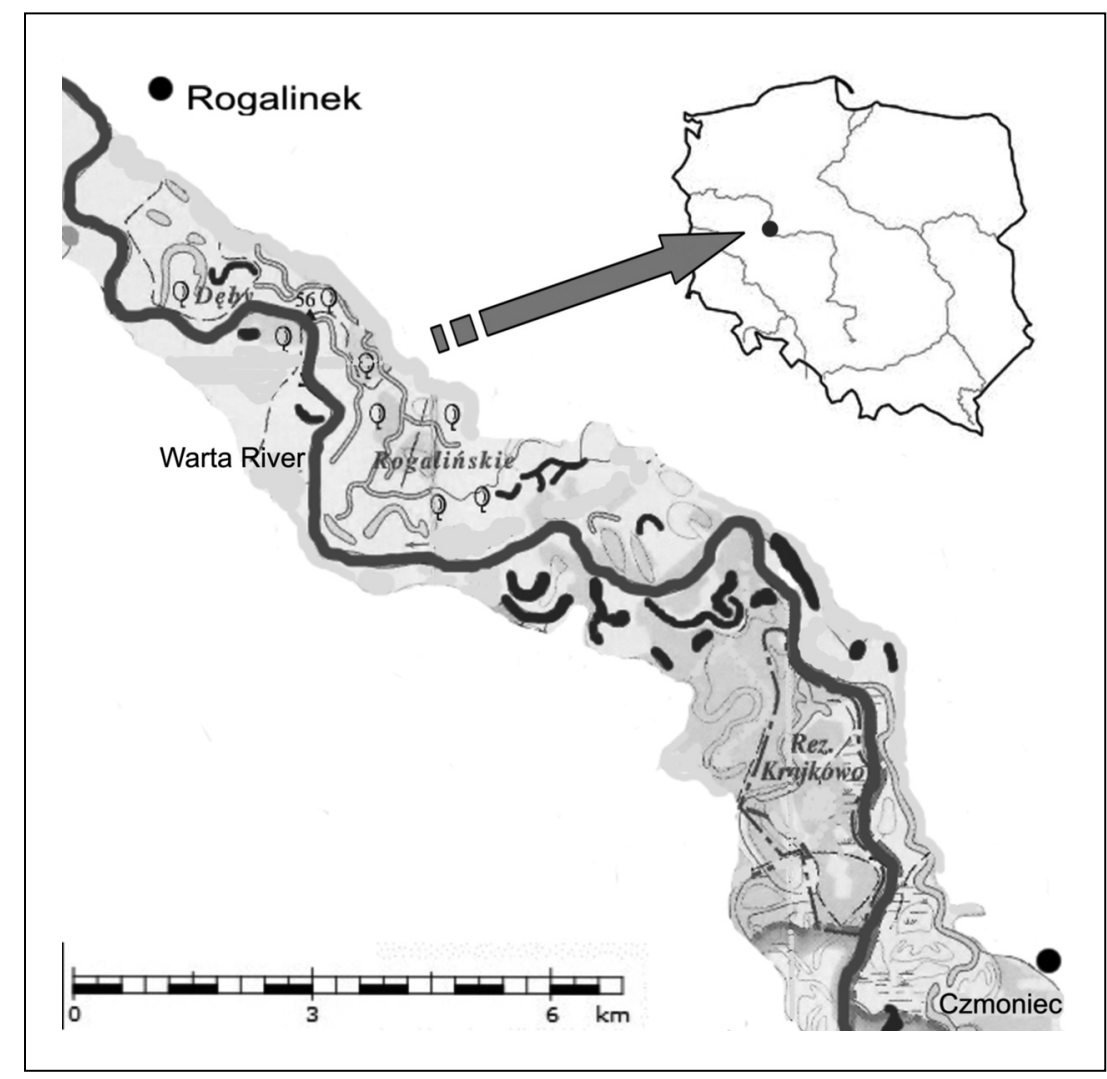

Figure 1. Location of researched oxbow lakes and the study area on the map of Poland. Ubicación de sistemas estudiados y del área de estudio en el mapa de Polonia. 
preceding this study, they have intensified and occurred every year in the spring as follows: in April of 2006, in March and April of 2007, and in February of 2008 (Fig. 2). Water overflow and inundation of the floodplain and oxbows occurs when the water level reaches $360-370 \mathrm{~cm}$; limnophase occurs at ca. $260 \mathrm{~cm}$.

The study area included the valley of River Warta (Fig. 1) from $281.0 \mathrm{~km}$ of the river $\left(52^{\circ}\right.$ $\left.10^{\prime} 46^{\prime \prime} \mathrm{N}, 17^{\circ} 00^{\prime} 11^{\prime \prime} \mathrm{E}\right)$ to $270.0 \mathrm{~km}\left(52^{\circ} 14^{\prime} 50^{\prime \prime} \mathrm{N}\right.$, $\left.16^{\circ} 53^{\prime} 46^{\prime \prime} \mathrm{E}\right)$. This section of the river valley is rich in oxbow lakes of different depth and areas, which are surrounded by marshes and meadows. Large areas occupied by meadows, along with oxbows, rushes and riparian herbaceous plants, form a spatial mosaic of habitats. The glacial valley of the River Warta lies entirely within an area covered by various forms of conservation, the Nature 2000 PLH300012 Rogalin Warta Valley. The study area represents an extensively managed landscape with high values for nature and biodiversity. In addition to the riparian forests of oak, elm and ash, extensively-used lowland fresh meadows, alluvial and aquatic habitats also occur.

\section{MATERIAL AND METHODS}

The examination of the zooplankton and the physical-chemical features of the water were carried out in spring and summer 2008 on 18 oxbows that varied in size (0.02-5.75 ha), depth (0.4-3.5 m), distance from the River Warta (100$550 \mathrm{~m})$ and the type of immediate catchment land use (pastoral vs. forest). Eight oxbows, which are located on the right bank of the Warta, were agricultural land, whereas in the case of the water bodies located on the left side of the river, four oxbows were surrounded by forest, and six by, agricultural farmlands. The studied oxbows were in limnophase after a decline of the water level to a steady state $(260 \mathrm{~cm})$. In all examined ponds, stands located in the open water zone, an area with no macrophytes overgrowing the bottom sediments, were chosen. In the case of five oxbows, additional stations dominated by

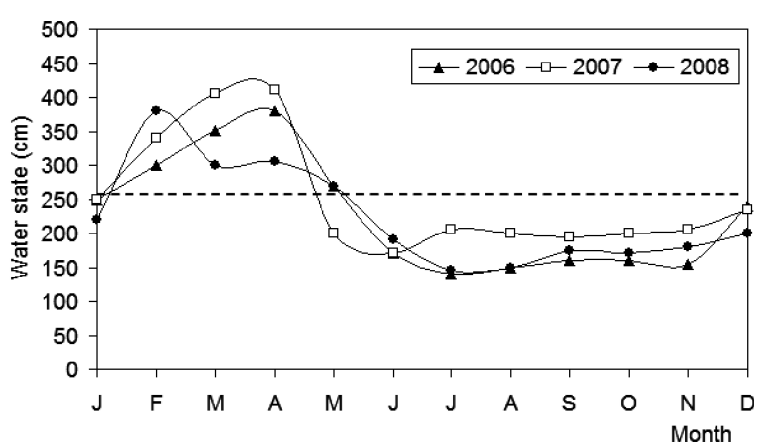

Figure 2. Annual changes in the water level in the River Warta from 2006-2008 (dashed line-average state). Variaciones anuales del nivel del agua en el río Warta en el periodo 20062008 (línea discontinua-nivel promedio).

macrophytes (elodeids) were also taken into consideration. The presence of fish and the level of overshading of the oxbow relative to the percentage of the tree and shrub band (Tree), as well as the vegetation cover relative to the percentage of the water surface overgrown by pleustophytes (Cover), were evaluated throughout the observation period. All oxbows were closed units in the hydrological sense (with no canal connections to the River Warta).

Rotifers and crustaceans were sampled in triplicate $(n=148)$. Five-litre samples of water were taken from the subsurface layer (from a boat, without disturbing the sediments), passed through a plankton net $(45 \mu \mathrm{m})$ and immediately preserved in $4 \%$ formalin. The zooplankton was counted in $1.0 \mathrm{ml}$ of the sample, which was equivalent to $1 \mathrm{~L}$ of pond water. There were 37 stations in the 18 examined oxbows, among which 32 samples were taken from the open-water zone, and 5, from the elodeids. Simultaneously, at midday, water samples were taken from the same sites for the physical-chemical analysis. Thirteen parameters were used to describe the characteristics of the aquatic environment of the studied oxbows. The water temperature, dissolved oxygen (DO), $\mathrm{pH}$, electric conductivity (EC) (Hanna Instruments) and light conditions (Light) with a Secchi disk were measured directly at the sampling sites. The water samples for chemical analysis from each vegetation zone and the open water were decanted separately into polyethylene 
flasks. In the laboratory, the following parameters were analysed spectrophotometrically: total phosphorus (TP, after hot acid digestion with persulfate), total reactive phosphorus (TRP, using the molybdate method), nitrate $\left(\mathrm{N}-\mathrm{NO}_{3}\right.$, with sodium salicylate), ammonium $\left(\mathrm{N}-\mathrm{NH}_{4}\right.$, with the Nessler method), and total hardness (Hard, by EDTA titration). Water colour (WC) was measured after filtration (membrane filters, pore $0.45 \mu \mathrm{m})$ at $436 \mathrm{~nm}$, and the dissolved organic substances (DOM), at $254 \mathrm{~nm}$ using a Cadas 200 UV-VIS (Dr Lange) spectrophotometer with a $50 \mathrm{~mm}$ quartz cell against deionized water (APHA, 1998). Chlorophyll $a$ (Chl) was determined after extraction with ethanol (ISO 10260). Trophic status was evaluated according to Carlson's classification (Carlson, 1977).

The t-test was applied to evaluate the differences in abiotic parameters in particular seasons (Statistica 10.0). A Principal Component Analysis (PCA) was used to identify the effect of the following environmental factors: the type of habitat (Water and Elodeids), the type of pond surroundings (Field and Forest), the presence of fish (Fish), the \% coverage of the pond surface by pleustophytes (Cover), the abiotic parameters (EC, WC, Chl, $\mathrm{NO}_{3}, \mathrm{NH}_{4}$, Hard, trophic state index - TSI, TP, Light) and the DOM on the following zooplankton community indices: the number of species (rotifer - N Rot, crustaceans - N Crust), the abundance of community (rotifer - nRot, crustaceans - nCrust), and the Shannon-Weaver indices of rotifer (Sh-W Rot) and crustaceans (Sh-W Crust). Both the zooplankton indices and environmental features were active variables. To describe the environmental preferences of particular species of zooplankton, the constrained ordination method was applied using CANOCO software (ter Braak, 1998). Due to the length of the longest gradient, which was lower than 3.0, Redundancy Analysis (RDA) was used. For the zooplankton species and chemical data, a square root transformation was performed to normalize their distribution.

\section{RESULTS}

\section{Environmental parameters}

Taking into account the specificity of the chemistry of the studied oxbows, which underwent (frequent periodic) allochtonic interactions with the river, the study of the physical-chemical parameters showed no significant seasonal variability. This means that the quality of the water in the water bodies was made uniform by river action and that the obtained differences were miniscule in character and limited to individual oxbows in relation to their physiographic surrounding environment, different morphometry and potential impacts arising from the distance of the pond from the river. Water reactivity from neutral to slightly alkaline was a characteristic feature of the chemistry of the investigated water bodies. Moderate hardness and mineralization were recorded. Based on a comparison of the abiotic data of the oxbow water between spring and

Table 1. Characteristics of the abiotic features of the water during study seasons (mean \pm standard deviation) and statistically significant differences (t-test). Características de los parámetros abióticos del agua durante las estaciones estudiadas (media \pm desviación estándar) y resultados de las diferencias estadísticamente significativas ( $t$-test).

\begin{tabular}{|c|c|c|c|c|c|c|c|c|c|c|c|c|}
\hline $\begin{array}{l}\text { Paramete } \\
\text { Season }\end{array}$ & $\begin{array}{c}\text { er Temp. } \\
\quad\left({ }^{\circ} \mathrm{C}\right)\end{array}$ & $\begin{array}{c}\text { EC } \\
(\mu \mathrm{S} / \mathrm{cm})\end{array}$ & $\mathrm{pH}$ & $\begin{array}{c}\text { DO } \\
(\mathrm{mg} / \mathrm{l})\end{array}$ & $\begin{array}{l}\text { DOM } \\
\left(\mathrm{m}^{-1}\right)\end{array}$ & $\begin{array}{c}\text { WC } \\
(\mathrm{mg} \mathrm{Pt} / \mathrm{l})\end{array}$ & $\begin{array}{c}\mathrm{TP} \\
(\mathrm{mg} \mathrm{P} / \mathrm{l})\end{array}$ & $\begin{array}{c}\text { TRP } \\
\left(\mathrm{mg} \mathrm{PO}_{4} / \mathrm{l}\right)\end{array}$ & $\begin{array}{c}\mathrm{N}-\mathrm{NH}_{4} \\
(\mathrm{mg} / \mathrm{l})\end{array}$ & $\begin{array}{l}\mathrm{N}-\mathrm{NO}_{3} \\
\left(\mathrm{mg} / \mathrm{l}^{1}\right)\end{array}$ & $\begin{array}{c}\text { Hard } \\
(\mathrm{mval} / \mathrm{l})\end{array}$ & $\begin{array}{c}\text { Chl } \\
(\mu \mathrm{g} / \mathrm{l})\end{array}$ \\
\hline$N=18$ & $17.8 \pm 1.2$ & $627 \pm 80$ & $7.6 \pm 0.2$ & $5.9 \pm 3.9$ & $46.1 \pm$ & $59 \pm 17$ & 0.35 & $0.63=$ & $0.59 \pm$ & 0.14 & $7.7 \pm 3.4$ & $22.2 \pm 35.0$ \\
\hline $\begin{array}{l}\text { Summer } \\
N=20\end{array}$ & $20.7 \pm 2.3$ & $585 \pm 125$ & $7.9 \pm 0.6$ & $5.1 \pm 2.8$ & $54.8 \pm 35.7$ & $65 \pm 30$ & $0.26 \pm 0.22$ & $0.67 \pm 0.64$ & $1.37 \pm 1.43$ & $0.08 \pm 0.04$ & $5.8 \pm 2.4$ & $34.3 \pm 46.2$ \\
\hline t-test & $-6.16^{* * *}$ & $1.00^{N S}$ & $-1.28^{N S}$ & $0.91^{N S}$ & $-0.62^{N S}$ & $-1.33^{N S}$ & $0.72^{N S}$ & $-0.31^{N S}$ & $-2.40 *$ & $5.32 * * *$ & $3.00 * *$ & $-1.41^{N S}$ \\
\hline
\end{tabular}

$* * * p<0.001 ; * * p<0.01 ; * p<0.05 ;{ }^{N S}$ not significant. 


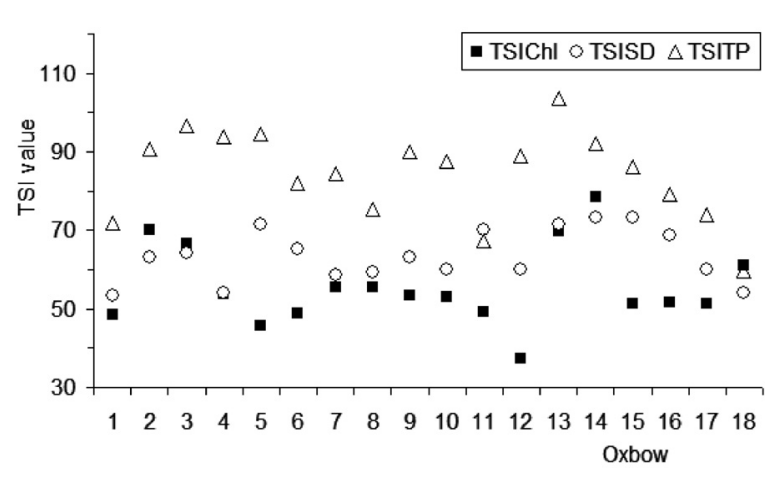

Figure 3. Water trophic status of the oxbow lakes. Estado trófico de los meandros abandonados.

summer, no statistically significant differences were observed for most of the studied parameters (Table 1). However, significant differences were noted in the cases of the temperatures and the concentrations of nitrogen compounds and bivalent cations. The transparency of the water and thus the light conditions were favourable because although Secchi depth rarely exceeded $1 \mathrm{~m}$, the maximum depth was quite shallow; therefore, light usually penetrated to the bottom. The light conditions were shaped mainly by abiotic factors. The impact of the phytoplankton (expressed by chlorophyll $a$ concentration) on water clarity was much lower than its impact on water colour (Pearson's correlations $r=-0.35, p<0.047$ and $r=-0.58, p<0.000$, respectively). The same effect was noted even in summer, when in spite of a larger biomass, the influence of the phytoplankton was negligible, but the water colour was high $(r=-0.78, p<0.000)$. The colour of the water varied (15-110 mg Pt/l) and was generally high (62 mg Pt/l on average). A similar finding was noted for the content of the DOM, where due to the large scatter of the results $\left(11.7-126.4 \mathrm{~m}^{-1}\right)$, the average value was still very high (Table 1$)$. The oxygen concentrations were quite variable from extremely low $\left(<1.0 \mathrm{mg} \mathrm{O}_{2} / \mathrm{l}\right)$ to very high (15.0 $\left.\mathrm{mg} \mathrm{O} \mathrm{O}_{2} / \mathrm{l}\right)$. The concentrations of the mineral nutrients, especially those of phosphorus and ammonium nitrogen, were high and suggested a eutrophic state of the water. An analysis of the trophic state of the water confirmed that the oxbows were generally eutrophic (Fig. 3). The values of the main index of the trophic state
- $\mathrm{TSI}_{C h l}$, as well as auxiliary $\mathrm{TSI}_{S D}-$ located most oxbows within or close to the range that characterized the eutrophic state (50-70). Meanwhile, the concentrations of the total phosphorus were so high that the $\mathrm{TSI}_{T P}$ index was usually higher than 70 (the lower border of hypereutrophy).

\section{Zooplankton}

We used PCA to identify the relationships between the environmental factors and the zooplankton community indices (Fig. 4). Species richness, as well as the Shannon-Weaver index of diversity, which was negatively correlated with the EC and trophic state, as well as with high values of water colour, were highest in the same habitat - elodeids - in the cases of both groups of zooplankton, the rotifers and crustaceans. By contrast, the open water area was characterized by the lowest diversity indices. Moreover, these diversity indices were positively affected by light penetration in the water column of the examined oxbows.

High rotifer numbers were found in the open water zone and were associated with total phosphorus content and conductivity. On the other hand, crustacean abundance was dependent on the level of the water surface overshading that resulted from the cover of pleustophytes and the concentration of nitrates and water hardness. Moreover, the crustaceans increased their densities in accordance with the decreasing role of the fish in the studied oxbows.

The type of surrounding area (forest vs. agricultural land use) together with the presence of vertebrate predators (fish) did not have a strong effect on the diversity of the zooplankton communities or their densities (Fig. 4). Of 143 taxa of Rotifera and 55 of Crustacea that were found during both periods of investigation, which were carried out in 18 oxbows, 20 species identified as rare or infrequently occurring in the Polish fauna were encountered as follows: Cephalodella nana Myers, C. obvia Donner, C. mus Wulfert, Colurella tesselata (Glascott), Euchlanis triquetra Ehrenberg, Lecane nana (Murray), L. pyriformis (Daday), Lepadella elliptica Wulfert, L. triba Myers, Microcodon clavus Ehrenberg, 

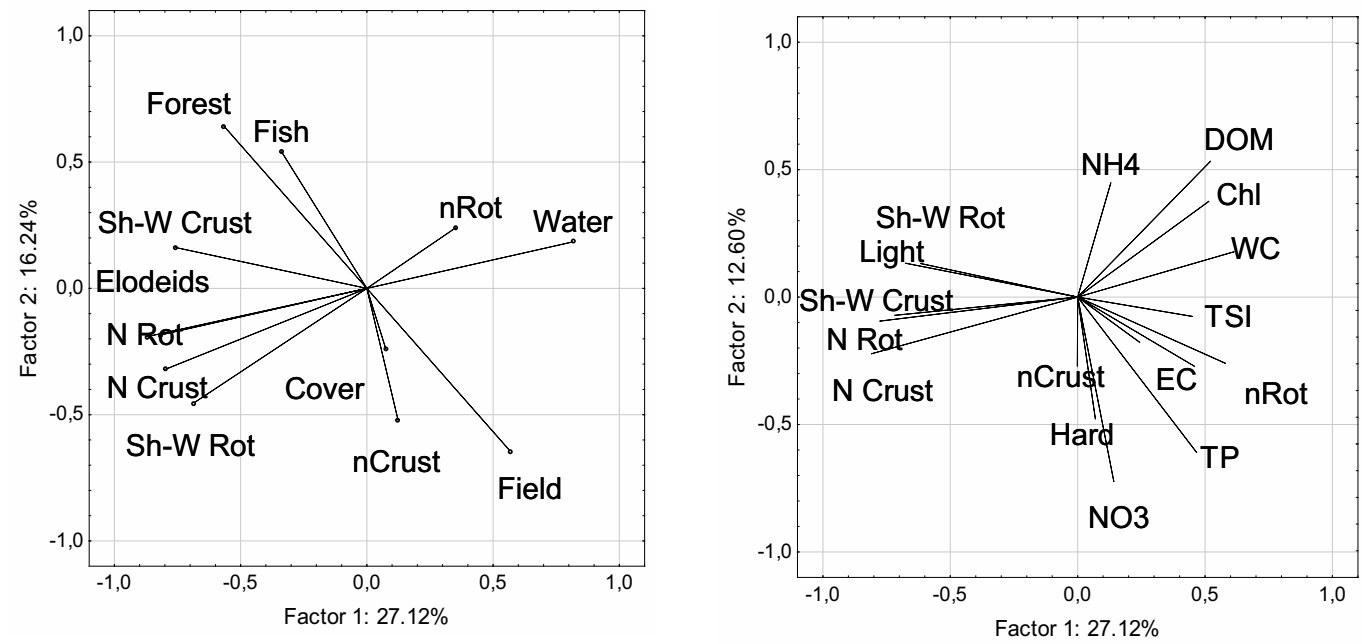

Figure 4. PCA ordination diagram of zooplankton community indices with environmental factors (habitat type, type of land use, macrophyte coverage, presence of fish) (left figure) and physical-chemical features of the water (right figure). Análisis de Componentes Principales (PCA) de los parámetros ambientales (tipo de hábitat, uso del suelo, cobertura de macrofitas, presencia de peces) (figura izquierda); y de los índices de la comunidad de zooplancton y las características químicas del agua (figura derecha).

Ploesoma truncatum (Levander), Trichocerca bidens (Lucus), T. iernis (Gosse) and Paracyclops affinis (Sars).

The results of the RDA, which was used to define the relationships between zooplankton and the environmental variables, indicated that there were three groups of particular species of rotifers and crustaceans (Fig. 5). The first group mainly consisted of pelagic rotifers (e.g., Keratella cochlearis, K. cochlearis f. tecta, K. quadrata, Polyarthra remata, $P$. vulgaris, Pompholyx complanata). Their occurrence was positively affected by ammonium concentrations, food source factors (chlorophyll $a$ concentration and DOM) and the presence of fish. These species gathered in the open water areas of the examined oxbows. Among them, the presence of some humic species (Radwan et al., 2004) such as Keratella testudo or $K$. ticinensis, which seemed to be strongly attributed to dissolved organic matter and fish, was recorded. The second set of species was composed of crustaceans of mainly pelagic origin (e.g., Bosmina coregoni, Daphnia longispina, Eudiaptomus gracilis, Thermocyclops oithonoides), the occurrence of which was positively associated with water hardness and negatively with phosphorus, as well as with oxbows surrounded by trees (Fig. 5). A large rep- resentation of eutrophic species (Brachionus angularis, Filinia longiseta, K. cochlearis f. tecta, K. quadrata, Bosmina longirostris, Chydorus sphaericus, $T$. oithonoides) was recorded in the studied water bodies; however, they were found scattered over both groups of pelagic species.

Finally, all typically littoral species, both species of rotifers and crustaceans (e.g., Bdelloidae, Cephalodella ventripes, Colurella uncinata, Lecane closterocerca, L. luna, Lepadella patella, Testudinella patina, Acroperus harpae, Harpacticoidae, Pleuroxus aduncus), were found to be attributed to the ponds with very good light conditions, high concentrations of total reactive phosphorus, and high percentages of surrounding trees and pleustophyte cover. These zooplankton species occurred in conjunction with macrophyte-dominated stations, elodeids. Moreover, they were negatively associated with water colour, DOM, chlorophyll and ammonia concentrations, as well as fish (Fig. 5).

\section{DISCUSSION}

Oxbows, which are water bodies located in the valleys of large lowland rivers, perform many important functions. From a biological point of 
view, their role as centres of biodiversity with respect to the occurrence of various groups of organisms associated with the river, as well as semiautonomic communities, should be especially emphasized. The complex interactions between the microhabitats and biocoenoses such as plankton, benthos, periphyton or fish occur here; therefore, biodiversity can reach a high level. It is known that river floods may cause at least a partial replacement of the organisms in the oxbow and a change in abiotic conditions. Flooding is critical and may even be degrading to the reservoir; floodwaters usually completely eliminate planktonic biota and aquatic vegetation by mechanical removal, although these organisms can perish due to the absence of light (Cronk \& Fennessy, 2001; Scheffer, 2004). We asked the question as to how stressful the inundation of an oxbow by the river during a flood may be to the zooplankton and whether and to what extent this factor will determine the diversity of organisms. As flood pulses may accelerate oxygenation of the water and decomposition processes in related aquatic envi-

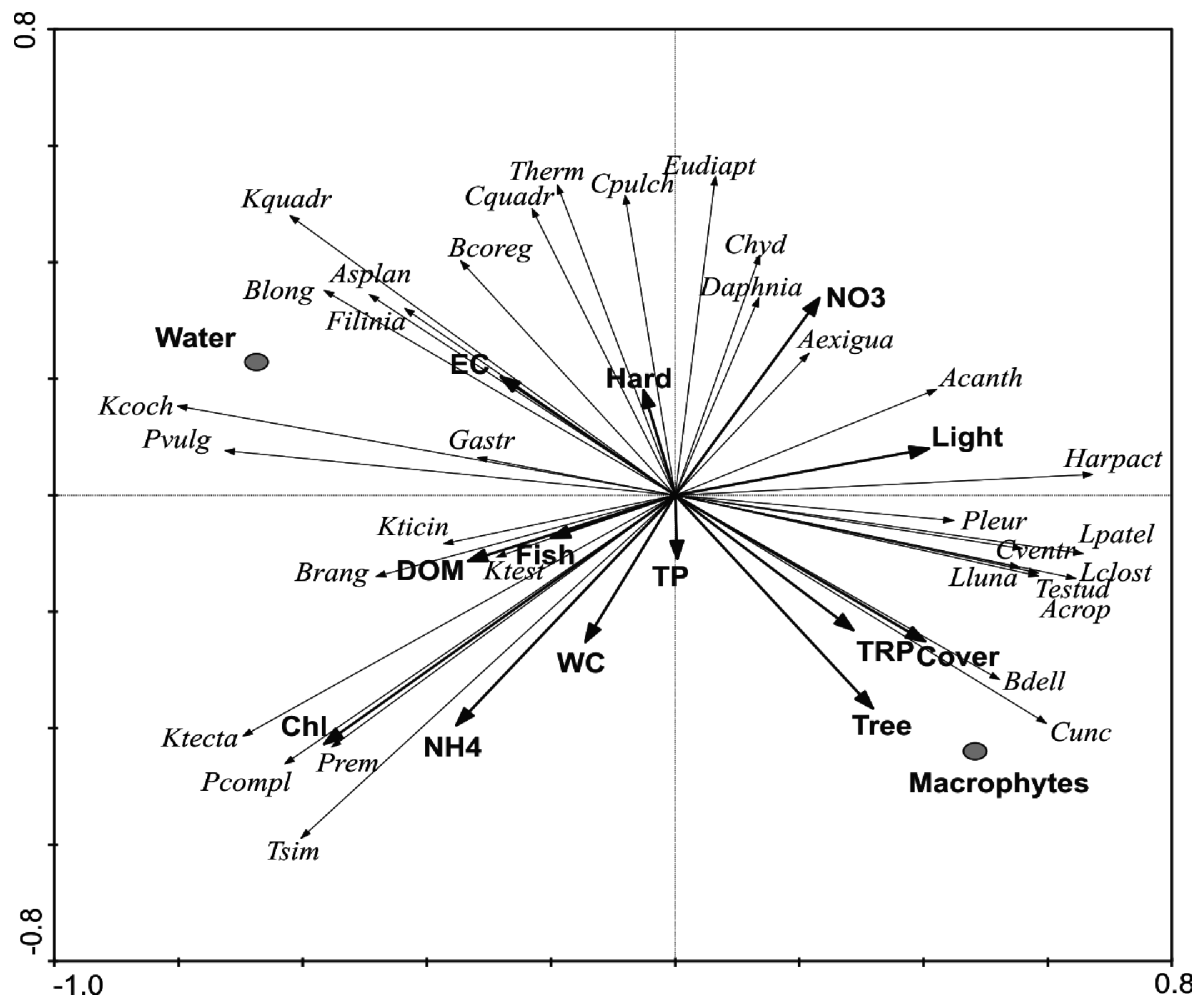

Figure 5. RDA diagram of zooplankton species (ind/l) and environmental parameters: Axis 1, 24.0\% of explanation; Axis $2,10.2 \%$ of explanation (abbreviations: Water - open water, Macrophytes - elodeids; physical-chemical parameters: EC, NO3, NH4, WC, TRP, Chl, Light, Hard, DOM; Tree-\% of tree surrounding; Cover-\% of pleustophytes; Fish-fish presence). Zooplankton species displayed are as follows: rotifers: Asplan-Asplanchna priodonta, Bdell-Bdelloidae, Brang-Brachionus angularis, Cventr-Cephalodella ventripes, Cunc-Colurella uncinata, Filinia-Filinia longiseta, Gastr-Gastropus hyptopus, Kcoch-Keratella cochlearis, Ktecta-Keratella cochlearis f. tecta, Kquadr-Keratella quadrata, Ktest-Keratella testudo, Kticin-Keratella ticinensis, Lclost-Lecane closterocerca, Lluna-Lecane luna, Lpatel-Lepadella patella, Prem-Polyarthra remata, Pvulg-Polyarthra vulgaris, Pcompl-Pompholyx complanata, Testud-Testudinella patina, Tsim-Trichocerca similis; crustaceans: Acanth-Acanthocyclops sp., Acrop-Acroperus harpae, AexiguaAlonella exigua, Bcoreg-Bosmina coregoni, Blong-Bosmina longirostris, Cpulch-Ceriodaphnia pulchella, Cquadr-Ceriodaphnia quadrangula, Chydorus sphaericus, Daphnia-Daphnia longispina, Eudiapt-Eudiaptomus gracilis, Harpact-Harpacticoidae, PleurPleuroxus aduncus, Therm-Thermocyclops oithonoides. Análisis de redundancia (RDA) de las especies de zooplancton (ind/l) y los parámetros ambientales. Eje 1, explica el $24.0 \%$ de la varianza; Eje 2, $10.2 \%$ de la varianza (abreviaturas: Water-aguas abiertas, Macrophytes-elodeas; parámetros físico-químicos: EC, NO3, NH4, WC, TRP, Chl, Light, Hard, DOM; Tree-\% de árboles alrededor; Cover-\% de pleustofitas; Fish-presencia de peces). 
ronments, we wondered whether this would have a positive effect on zooplankton species diversity, as has been stated in some cornerstone papers referring to the flood pulse concept (Junk et al., 1989; Tockner et al., 2000). As almost 200 zooplankton taxa, among which 20 rare species or those that occur only infrequently in the Polish fauna, were encountered and identified during the two periods of our study carried out on the 18 oxbows, we consider that oxbows are very important habitats for zooplankton. This is why we obtained such a high level of zooplankton diversity. Moreover, PCA identified the level of heterogeneity, referring to the type of habitat, as the most important factor for both species richness and the Shannon-Weaver index of zooplankton diversity. Their highest values, negatively correlated with EC, trophic state and high WC and positively correlated with the depth of light penetration, were recorded in the most complex habitat - elodeids - in the case of both groups of zooplankton - rotifers and crustaceans.

In contrast to the diversity indices, the abundance distribution revealed a different pattern for particular groups of zooplankton. High rotifer numbers were found in the open water zone and were associated with phosphorus (TP) and different mineral substances (EC). On the other hand, crustacean abundance was dependent on the level of the water surface overshading by the cover of pleustophytes and also on the concentration of nitrates and the water hardness.

Although the type of catchment land use is often responsible for the creation of various communities of zooplankton (Dodson et al., 2007), in the case of the examined oxbows, the type of surrounding area (forest vs. field land use) did not have any pronounced effect either on the diversity features of the zooplankton communities or on their densities. Furthermore, the presence of fish did not affect the zooplankton community indices, although the effect of fish was visible in the case of the distribution of particular zooplankton species.

Our knowledge of the effect of the environmental factors structuring freshwater food webs is still rudimentary, especially relating to the origins, land uses in the surrounding area or vari- ations in the habitat specificity of a water body. However, the role of microscopic-sized animals such as rotifers or crustaceans, which may reach great abundance, can be very influential. The very diverse environmental factors that occur in small water bodies, especially in the case of oxbows, which undergo frequent flooding, may be responsible for the creation of a large number of available ecological niches. Therefore, many organisms can be found within even a small area of ponds, and different factors may lead to their co-occurrence. The results extracted by RDA suggest that the zooplankton species were segregated throughout the area of the examined oxbows and that different environmental parameters were responsible for their occurrence. Although floodwaters may contribute to the elimination of aquatic vegetation, it was found that the division of the zooplankton species relative to habitat requirements was striking. Typically, littoral species were grouped together around water bodies with a high level of light penetration and high content of total reactive phosphorus. High concentrations of TRP occur in habitats with abundant periphytic communities where high phosphorus release occurs (Doods, 2003; Rier \& Stevenson, 2006). Such conditions favour littoral species that may feed by scraping food particles from the surface, feeding on epiphytic algae or consuming organic matter accompanied by bacteria and protozoans. There are similarities between littoral and planktonic organisms in relation to the type and availability of food. However, compared with planktonic organisms, their species diversity is very high, and little is known about their biology, including their feeding habits (Enríquez García et al., 2003). Moreover, littoral species prefer oxbows with a high level of overshading caused by the amount of the surrounding trees and the surface cover created by the pleustophytes. Similar to the values of zooplankton species richness and the Shannon-Weaver index, particular littoral species were also found to occur in proximity to macrophyte-dominated stations -elodeids, contrary to the second ecological group - pelagic zooplankters, which were associated with the open water zone. Rotifer species such as Kera- 
tella cochlearis, Keratella quadrata, Polyarthra vulgaris or Pompholyx complanata were found to be grouped around oxbows with high concentrations of ammonium and high food source indices (chlorophyll $a$ concentration and dissolved organic matter), as well as large numbers of fish.

The available literature does not provide a basis for the identification of the habitat characteristics for zooplankton in riparian wetlands, especially in oxbows after floods (eg. Havel et al., 2000; Napiórkowski \& Napiórkowska, 2014). Among the pelagic community of zooplankters, a large representation of the species indicating eutrophic conditions and both rotifers and crustaceans such as Brachionus angularis, Filinia longiseta, Keratella cochlearis f. tecta, Keratella quadrata, Bosmina longirostris, Chydorus sphaericus, Thermocyclops oithonoides (Karabin, 1985) was found. These species were not grouped together, which suggests the generally eutrophic character of the water of all the examined oxbows. This was confirmed by the physical-chemical results. The intensive fertilization of the water bodies in the river valley is a result of negligence in the field of environmental protection. Moreover, five large cities discharged urban and industrial effluents with only the first degree of purification (mechanical) directly into the river until almost the end of the $20^{\text {th }}$ century. Consequently, the ecological status of the river was disastrous, and its quality, very low (Michałkiewicz et al., 2011).

An interesting feature of most oxbow lakes is the high values of DOM, indicating the occurrence of organic carbon bound with organic substances, such as humic substances (Joniak et $a l ., 2007)$. The large variability and the high content of DOM indicated the important role of an external supply of organic matter, which is impossible to produce in other types of isolated lakes, with the exception of natural polyhumic lakes (Klimaszyk \& Joniak, 2007). A similar high changeability of the oxygen concentrations between oxbows was most likely the effect of the high the intensity of oxidation due to the excess of organic pollution. The lack of correlation between the concentration of the oxygen and chlorophyll shows that the potential for the production of oxygen via photosynthesis was insufficient to ensure good oxygen conditions. Such a phenomenon is typical for lakes overloaded with mineral compounds (Osgood \& Stiegler, 2007; Sobczyński \& Joniak, 2013), as well as for small water bodies polluted with slurry (KuczyńskaKippen et al., 2009).

Meanwhile, humic species of rotifers occurred in the investigated oxbows in conjunction with dissolved organic matter and fish. Keratella testudo is known to utilize, apart from Euglenoides and Cryptomonadales, large amounts of detrital material accompanied by bacteria (Pourriot, 1977). This confirms its close association with DOM (representing a wide spectrum of organic compounds), which is very susceptible to decomposition by planktonic heterotrophic bacteria (Mudryk \& Skórczewski, 2006). Furthermore, in the case of the studied oxbows, 20 rare species or species infrequent for Polish fauna were noted. Such a great representation may suggest highly variable environmental conditions suitable for zooplankton development in the analysed oxbows, which is similar to other types of wetlands and floodplains, which provide essential habitats for riverine biota (Górski et al., 2013). Rotifers and smaller cladocerans and copepods are usually more abundant and diverse in floodplain wetlands and riverine lakes, where a range of microhabitats are available compared with main river channels (Siziba et al., 2012). Greater than $10 \%$ of the taxonomic structure that is represented by rare species points to a need for the protection of these faunistically valuable ponds. However, it may also suggest a lack of a thorough examination of macrophyte-dominated areas in small aquatic ecosystems as these species belong to typical littoral forms (Radwan et al., 2004).

In summary, despite the fact that the abiotic parameters in the examined oxbows of a large lowland river valley were unstable and disturbed due to their temporary nature, there was a broad diversity of zooplankton communities. Interpretation of the data in terms of the habitat requirements of the zooplankton community is fraught with a high degree of uncertainty because 
it is not known whether the state is permanent or only temporary. The PCA analysis, which showed that the habitat parameters are separated from the zooplankton indices, illustrated the problem well. However, the results of the RDA analysis suggest that particular rotifer and crustacean species were segregated throughout the area of the studied oxbows as regards certain ecological groups or taxonomic affiliations. Moreover, a very diverse species composition and a relatively high level of participation of rare species (over 10\% of taxonomic structure) was observed in the examined oxbows, which confirms the flood pulse concept, especially the transitional phase (between flooding and stability) of the investigated oxbows.

\section{ACKNOWLEDGEMENTS}

This work was supported by the Polish State Committee for Scientific Research as research project No. N N305 042739.

\section{REFERENCES}

APHA 1998. Standard methods for the examination of water and wastewater. $20^{\text {th }}$ edition. Am. Public Health Assoc., Washington.

CARLSON, R. E. 1977. A trophic state index for lakes. Limnology and Oceanography, 22: 361369.

CRONK, J. K. \& M. S. FENNESSY. 2001. Wetland plants: biology and ecology. CRC Press.

DODSON, S. J., W. R. EVERHAST, A. K. JANDL \& S. J. KRAUSKOPF. 2007. Effect of watershed land use and lake age on zooplankton species richness. Hydrobiologia, 579: 393-399.

DOODS, W. K. 2003. The role of periphyton in phosphorus retention in shallow freshwater aquatic systems. Journal of Phycology, 39: 840-849.

ENRÍQUEZ GARCÍA, C., S. NANDINI \& S. S. S. SARMA. 2003. Food type effects on the population growth patterns of littoral rotifers and cladocerans. Acta hydrochimica et hydrobiologica, 31(2): 120-133.

GALLARDO,B., C. ESPAňOL \& F. A. COMIN. 2012. Aquatic metabolism short-term response to the flood pulse in a Mediterranean floodplain. Hydrobiologia, 693(1): 251-264.

GÓRSKI, K., K. J. COLLIER, I. C. DUGGAN, C. M. TAYLOR \& D. P. HAMILTON. 2013. Connectivity and complexity of floodplain habitats govern zooplankton dynamics in a large temperate river system. Freshwater Biology, 58(7): 1458-1470.

GRABOWSKA, M., K. GLIńSKA-LEWCZUK, K. OBOLEWSKI, P. BURANDT, S. KOBUS, J. DUNALSKA, R. KUJAWA, A. GOŹDZIEJEWSKA \& A. SKRZYPCZAK. 2014. Effects of hydrological and physicochemical factors on phytoplankton communities in floodplain lakes. Polish Journal of Environmental Studies, 23(3): 713-725.

GÜNTZEL, A. M., E. A. PANARELLI, W. M. da SILVA \& K. F. ROCHE. 2010. Influence of connectivity on Cladocera diversity in oxbow lakes in the Taquari River floodplain (MS, Brazil). Acta Limnologica Brasiliensia, 22(1): 93-101.

HAVEL, J. E., E. M. EISENBACHER \& A. A. BLACK. 2000. Diversity of crustacean zooplankton in riparian wetlands: colonization and egg banks. Aquatic Ecology, 34: 63-76.

HUMPHRIES, P., R. A. COOK, A. J. RICHARDSON \& L. G. SERAFINI. 2006. Creating a disturbance: Manipulating slackwaters in a lowland river. River Research and Appplications, 22: 525-542.

JONIAK, T., N. KUCZYŃSKA-KIPPEN \& B. NAGENGAST. 2007. The role of aquatic macrophytes in microhabitatual transformation of physical-chemical features of small water bodies. Hydrobiologia, 584: 101-109.

JUNK, W. J., P. B. BAYLEY \& R. E. SPARKS. 1989. The flood pulse concept in river-floodplain systems. Canadian Special Publication of Fisheries and Aquatic Sciences, 106: 110-127.

JURKIEWICZ-KARNKOWSKA, E. 2006. Communities of aquatic Molluscs in floodplain water bodies of lowland river (Bug River, east Poland). Polish Journal of Ecology, 54(2): 253-266.

KARABIN, A. 1985. Pelagic zooplankton (Rotatoria + Crustacea). Variation in the process o lake eutrophication. Structural and quantitative features. Ekologia polska, 33: 567-616.

KLIMASZYK, P. \& T. JONIAK. 2007. Seasonal variability of thermal and oxygen conditions in midforest polyhumic lakes (western Poland). Limnological Review, 7(4): 195-199.

KUCZYŃSKA-KIPPEN, N., M. WIŚNIEWSKA \& T. JONIAK. 2009. Zooplankton community structure 
of five neighboring small water bodies of anthropogenic origin. TEKA Commission of Protection and Formation of Natural Environment, 6: 153161.

LACHAVANNE, J. B. \& J. RAPHAËLLE. 1997. Biodiversity in land-inland water ecotones. Taylor \& Francis.

MICHAŁKIEWICZ, M., B. MĄDRECKA, T. DYSARZ, T. JONIAK \& E. SZELĄG-WASIELEWSKA. 2011. The influence of the city of Poznan on the water quality of the Warta River. Science Nature Technologies, 5(5), \#89.

MUDRYK, Z. J. \& P. SKÓRCZEWSKI. 2006. Enzymatic activity and degradation of organic macromolecules by neustonic and planktonic bacteria in an estuarine lake. Polish Journal of Ecology, 54(1): 3-14.

NAIMAN, R. J. \& H. DÉCAMPS. 1990. The ecology and management of aquatic-terrestrial ecotones. CRC Press.

NAPIÓRKOWSKI, P. 2012. Influence of hydrological conditions on zooplankton of oxbow lakes (old riverbeds) of the Lower Vistula in the city of Torun. Limnological Papers, 4(1): 55-67.

NAPIÓRKOWSKI,P. \& T. NAPIÓRKOWSKA. 2014. The impact of catastrophic flooding on zooplankton. Polish Journal of Environmental Studies, 23: 409-417.

OBOLEWSKI, K. 2011. Macrozoobenthos patterns along environmental gradients and hydrological connectivity of oxbow lakes. Ecological Engineering, 37: 796-805.

OBOLEWSKI, K., GLIńSKA-LEWCZUK, K., \& S. KOBUS. 2009. An attempt at evaluating the influence of water quality on the qualitative and quantitative structure of epiphytic fauna dwelling on Stratiotes aloides L., a case study on an oxbow lake of the Łyna river. Journal of Elementology, 14(1): 119-135.

OSGOOD, R. A. \& J. E. STIEGLER. 2007. The effects of artificial circulation on a hypereutrophic lake. Journal of the American Water Resources Association, 28(2): 209-217.

PASZTALENIEC, A., M. KARPOWICZ \& M. STRZAŁEK. 2013. The influence of habitat con- ditions on the plankton in the Białe oxbow lake (Nadbużański Landscape Park). Limnological Review, 13(1): 43-50.

POURRIOT, R. 1977. Food and feeding habits of Rotifera. Archiv für Hydrobiologie, 8: 243-260.

RADWAN, S., I. BIELAŃSKA-GRAJNER \& J. EJSMONT-KARABIN. 2004. Rotifers Rotifera. Freshwater fauna of Poland. Tercja Press.

RIER, S. T., \& R. J. STEVENSON. 2006. Response of periphytic algae to gradients in nitrogen and phosphorus in streamside mesocosm. Hydrobiologia, 561: 131-147.

SCHEFFER, M. 2004. Ecology of shallow lakes. Kluwer Acad. Publish. Dortrecht.

SIZIBA, N., M. J. CHIMBARI, K. MOSEPELE, H. MASUNDIRE \& L. RAMBERG. 2012. Inundation frequency and viability of microcrustacean propagules in soils of temporary aquatic habitats of lower Okavango Delta, Botswana. Ecohydrology, 6(5): 722-730.

SOBCZYŃSKI, T. \& T. JONIAK. 2013. The variability and stability of water chemistry in deep temperate lake: Results of long-therm study of eutrophication. Polish Journal of Environmental Studies, 22(1): 227-237.

SYMONIDES, E. 2010. The role of ecological interactions in the agricultural landscape. Water-Environment-Rural Areas, 10, 4(32): 249-263.

SZELĄG-WASIELEWSKA, E., T. JONIAK, M. MICHAŁKIEWICZ, T. DYSARZ \& B. MADRECKA. 2009. Bacterioplankton of the Warta River in relation to physicochemical parameters and flow rate. Ecohydrology and Hydrobiology, 9(2-4): 225-236.

TER BRAAK, C. J. 1998. CANOCO - an extension of DECORANA to analyze species-environment relationships. Hydrobiologia, 184(3): 169-170.

TOCKNER, K., F. MALARD \& J. WARD. 2000. An extension of the flood pulse concept. Hydrological Process, 14: 2861-2883.

WILK-WOŹNIAK, E., S. LIGEZZA \& E. SHUBERT. 2013. Effect of water quality on phytoplankton structure in oxbow lakes under anthropogenic and non-anthropogenic impacts. Clean-Soil, Air, Water, 42(4): 421-427. 